\title{
Performance of Different Gladiolus (Gladiolus grandiflora L.) Cultivars for Plant Growth and Corm Production under Chhattisgarh Plains Agroclimatics Zone Condition
}

\author{
Shravan Kumar, T. Tirkey, Ram Singh ", Ishwar Ram Markam \\ and Durgeshwar Kumar Basant \\ Department of Floriculture and Landscape Architecture, IGKV, Raipur, \\ Chhattisgarh - 492 012, India \\ *Corresponding author
}

\section{A B S T R A C T}

\begin{tabular}{|l|}
\hline Ke y w o r d s \\
Gladiolus, \\
Cultivars, \\
Vegetative growth, \\
Corms and cormels \\
\hline Article Info \\
\hline $\begin{array}{l}\text { Accepted: } \\
\text { 20 September } 2020 \\
\text { Available Online: } \\
10 \text { October } 2020\end{array}$ \\
\hline
\end{tabular}




\section{Introduction}

Gladiolus (Gladiolus grandiflora L.) also known as "sword lily" belonging to family Iridaceae and is native of South Africa and Tropical Africa. It is one of the most popular flowers with magnificent inflorescence, referred as "Queen of bulbous flowers". It is herbaceous plant which develops from axillary buds on the corm, usually unbranched leafy, leaves basal and cauline and sword shaped (Goldblatt et al., 1998). Gladiolus possesses a great potential for export market, to European countries especially during winter. In Holland and other European countries it is very popular and ranks next to Tulip. In India too, gladiolus has become an important cut flower crop in the domestic flower market. Gladiolus is additionally useful for flower beddings in gardens, pot crops, rockeries etc (Abbasi et al., 2005).

The state of Chhattisgarh is one of the potential areas for commercial cultivation of Gladiolus. There is a heavy demand for flowers during marriage, festivals and other social functions. There is a big gap between supply and demand that local growers can use their advantage. Gladiolus is one of the dominant flowers in the flower market of Chhattisgarh is blessed with many natural advantages such as abundant sunshine and favourable temperatures for its growth. There is much scope for increase Gladiolus cultivation in Chhattisgarh. The performance of any crop or cultivar largely depends on genotypic constituent and effect of environmental condition. As a result, cultivars which perform well in one region may not perform the same in other regions of varying climatic conditions (Pandey, 2012). Hence, the present experiment was conducted to performance of different gladiolus cultivars for plant growth and corm production under Chhattisgarh plains agroclimatics zone condition.

\section{Materials and Methods}

An experiment entitled "Performance of different gladiolus cultivars for plant growth and corm production under Chhattisgarh plains agroclimatics zone condition" was carried out in Horticultural Research cum Instruction Farm at the Department of Floriculture and Landscape Architecture, College of Agriculture, Indira Gandhi Krishi Vishwavidyalaya, Raipur, (C.G.) India during October 2016-17. The experiment was laid out in Randomized Block Deign (RBD) with three replication. Healthy corms of fourteen varieties viz. Candyman, Nova Lux, Gunjan, Advantage, Punjab Dawn, Summer Sunshine, Her Majesty, Dull Queen, Saffron, GS-2, American Beauty, White Prosperity, Red Majesty, Fancy Pink. Standard cultivation and recommended cultural practices were followed. The plants were planting at a distance of $30 \times 20 \mathrm{~cm}$. Observations were recorded on various vegetative growth, corm and cormels yield attributes and data were analyzed statistically.

\section{Results and Discussion}

\section{Vegetative growth characters}

Various vegetative growth parameters were influenced significantly due to response of varieties (Table $1 \& 2$ ). The cultivar Punjab Dawn (8.67) taken minimum number of days to $50 \%$ sprouting which was at par with cultivar Candyman (9.33), Summer Sunshine (9.67), Saffron (9.67), American Beauty (9.67) and White Prosperity (9.67). Cultivar Punjab Dawn was significantly minimum days taken to $50 \%$ sprouting over others. The maximum number days (13.33) to taken 50\% sprouting was recorded in cultivar Gunjan during investigation.

The maximum $(49.11 \mathrm{~cm})$ plant height was recorded in cultivar Candyman at 20 DAP 
which was at par with cultivar White Prosperity $(47.94 \mathrm{~cm})$, Nova Lux $(47.57 \mathrm{~cm})$ and Advantage $(47.31 \mathrm{~cm})$. The minimum plant height was recorded in cultivar Dull Queen $(30.34 \mathrm{~cm})$.

The maximum $(72.31 \mathrm{~cm})$ plant height was recorded in cultivar Summer Sunshine at 40 DAP which was statistically at par with cultivar Candyman $(71.42 \mathrm{~cm})$, Nova Lux $(69.12 \mathrm{~cm})$, Red Majesty $(69.00 \mathrm{~cm})$, Advantage $(68.81 \mathrm{~cm})$ and GS-2 $(67.07 \mathrm{~cm})$ and minimum was observed in cultivar Dull Queen $(43.37 \mathrm{~cm})$.

At 60 DAP maximum plant height (100.21 $\mathrm{cm})$ was recorded in cultivar Candyman. Which was significantly superior to rest of the other cultivars. The minimum plant height was recorded in cultivar Dull Queen (53.70 $\mathrm{cm})$. The variation in plant height may be due to genetic makeup of the cultivar, which might differ variety to variety. Kumari and kumar (2015) reported that variation in final plant height among all the cultivars may be due to the hereditary traits or prevailing environmental conditions of the growing location.

The maximum (3.57) number of leaves was recorded in cultivar GS-2 which was at par with cultivar Candyman (3.43), White Prosperity (3.07), Gunjan (3.03), Punjab Dawn (3.00), Red Majesty (3.00) and Summer Sunshine (2.97) and significantly higher than rest of the other cultivars. Minimum (2.40) number of leaves was observed in cultivar Her Majesty at 20 DAP.

At 40 DAP highest number of leaves was recorded in cultivar Gujan (6.07) which was at par with cultivar GS-2 (5.83) and Advantage (5.77) and it was found superior over other cultivars at 40 DAP. The lower number of leaves was observed in cultivar Nova Lux (4.17).
In case of 60 DAP the higher (8.03) number of leaves was recorded in cultivar Candyman which was at par with cultivar White Prosperity (7.87), GS-2(7.67), Summer Sunshine (7.50), Gunjan (7.47), American Beauty (6.97) and Her Majesty (7.13). However, it was significantly superior then rest of the cultivars. The lowest number of leaves was recorded in cultivar Dull Queen (6.03). Significant variation was observed as to the number of leaves amongst the cultivars. The variation in number of leaves might be due to genotype as well as some known or unknown environmental factors. Similar results were also reported by Hossain et al., (2011).

The data on length of leaves was recorded at 20, 40 and 60 DAP. Significantly the maximum length of leaves $(25.67 \mathrm{~cm})$ was recorded in cultivar Candyman which was at par with cultivar Punjab Dawn $(24.26 \mathrm{~cm})$, Nova Lux $(24.20 \mathrm{~cm})$, American Beauty $(23.81 \mathrm{~cm})$, Advantage $(23.79 \mathrm{~cm})$, Red Majesty $(23.70 \mathrm{~cm})$, Gunjan $(23.23 \mathrm{~cm})$, Saffron (22.57), Fancy Pink $(21.80 \mathrm{~cm})$ and Summer Sunshine $(21.71 \mathrm{~cm})$. The lower length of leaves $(17.63 \mathrm{~cm})$ was noted in cultivar Dull Queen during the first growth stage.

Different cultivars shows significant impacts on length of leaves during 40 DAP. Higher leaves length $(38.29 \mathrm{~cm})$ was observed in cultivar Candyman which was at par with cultivar White Prosperity $(36.52 \mathrm{~cm})$, Nova Lux $(35.48 \mathrm{~cm})$ and significantly higher than rest of the other cultivars. The minimum length of leaves $(26.61 \mathrm{~cm})$ was noted in cultivar Dull Queen.

At 60 DAP significantly maximum length of leaves $(47.70 \mathrm{~cm})$ was recorded in cultivar White Prosperity which was at par with cultivar Candyman (47.00 cm), Nova Lux $(46.10 \mathrm{~cm})$ and Punjab Dawn $(45.29 \mathrm{~cm})$ and 
significantly differ with rest of the other cultivars. The lowest length of leaves was recorded $(37.14 \mathrm{~cm})$ in cultivar American Beauty. Differences in length of leaves might be due to genetic makeup of the cultivars, which is governed by the genotypic constituent of the plant. Similar results were also found by Kumar and Yadav (2005) and Swaroop et al., (2011).

The data in respect to gladiolus width of leaves was recorded at 20,40 and 60 DAP. Significantly higher width of leaves $(1.92 \mathrm{~cm})$ was observed in cultivar Candyman which was at par with cultivar Advantage $(1.80 \mathrm{~cm})$, Fancy Pink $(1.76 \mathrm{~cm})$, White Prosperity $(1.75$ $\mathrm{cm})$ and Red Majesty $(1.74 \mathrm{~cm})$ and it was found significantly differ with rest of the other cultivars. The lower width of leaves was recorded in cultivar Her Majesty $(1.09 \mathrm{~cm})$ at 20 DAP.

At 40 DAP maximum width of leaves (2.38 $\mathrm{cm}$ ) was observed in cultivar Candyman which was at par with cultivar White Prosperity $(2.36 \mathrm{~cm})$, Summer Sunshine (2.20 $\mathrm{cm})$, Fancy Pink (2.19 cm), Red Majesty $(2.13 \mathrm{~cm})$ and Advantage $(2.07 \mathrm{~cm})$. The lowest width of leaves $(1.22 \mathrm{~cm})$ was noted under cultivar Her Majesty.

During 60 DAP the cultivar White Prosperity gave maximum width of leaves $(2.81 \mathrm{~cm})$ which was at par with cultivar GS-2 (2.77 $\mathrm{cm})$, Summer Sunshine $(2.74 \mathrm{~cm})$, Gunjan $(2.71 \mathrm{~cm})$, Fancy Pink $(2.61 \mathrm{~cm})$ and Punjab Dawn $(2.50 \mathrm{~cm})$ and it was noted significantly differ with rest of the other cultivars. The minimum width of leaves was noted from cultivar Dull Queen $(1.74 \mathrm{~cm})$.

The variation in leaf width among the cultivars might be due to variation in their genetic constitution that could have lead to differential rates of photosynthesis and ultimately influence to vegetative growth and development of the plants. Variation in leaf width amongst gladiolus varieties has also been reported by Kumar and Yadav (2005).

\section{Corm and cormel attributes}

The maximum number of corms (4.69) per plant was recorded in cultivar Advantage followed by Saffron (3.82), Fancy Pink (3.73) and Nova Lux (3.48). However, it was found significantly differed to rest of the other cultivars of the gladiolus. Minimum number of corms (2.14) per plant was recorded in cultivar Summer Sunshine. Similar variation for number of corms plant ${ }^{-1}$ in gladiolus was also observed by Saini et al., (1991), Ravidas (1993), Shiramagond and Hanamashetti (1999), Neeraj et al., (2000), Rajiv and Yadav (2005), and Neha et al., (2012).

Significant differences were observed among the cultivars with respect to weight of corms per plant and ranged from $80.56(\mathrm{~g})$ to 21.15 (g). The maximum weight of corms per plant was recorded in cultivar Candyman $80.56(\mathrm{~g})$ and minimum weight of corms plant was recorded in cultivar Dull Queen 21.15 (g). Saini et al., (1991), Das (1998), Dimri (2002), Rajiv and Yadav (2005) and Rahul et al., (2011) also reported similar variations in weight of corms.

The maximum diameter of corm was recorded in cultivar Candyman $(6.46 \mathrm{~cm})$ and minimum was recorded in Dull Queen (3.27 $\mathrm{cm})$. This was significantly greater than other cultivars of the gladiolus. Neeraj et al., (2001), Ram et al., (2005), Naik et al., (2011) and Sankari et al., (2012) also observed similar variations for diameter of corm.

Significant variation was observed among cultivars of gladiolus with respect to number of cormels per plant. 
Table.1 Performance of different gladiolus cultivars for vegetative growth characters

\begin{tabular}{|c|c|c|c|c|c|c|c|c|c|c|c|c|c|}
\hline \multirow[b]{2}{*}{ Treatment } & \multirow{2}{*}{$\begin{array}{l}\text { Days to } \\
50 \% \\
\text { sprouting }\end{array}$} & \multicolumn{3}{|c|}{ Plant height $(\mathrm{cm})$} & \multicolumn{3}{|c|}{$\begin{array}{l}\text { Number of leaves } \\
\text { per plant }\end{array}$} & \multicolumn{3}{|c|}{ Length of leaves $(\mathrm{cm})$} & \multicolumn{3}{|c|}{ Width of leaves $(\mathrm{cm})$} \\
\hline & & $\begin{array}{c}20 \\
\text { DAP }\end{array}$ & $\begin{array}{c}40 \\
\text { DAP }\end{array}$ & $\begin{array}{c}60 \\
\text { DAP }\end{array}$ & $\begin{array}{c}20 \\
\text { DAP }\end{array}$ & $\begin{array}{c}40 \\
\text { DAP }\end{array}$ & $\begin{array}{c}60 \\
\text { DAP }\end{array}$ & $\begin{array}{c}20 \\
\text { DAP }\end{array}$ & $\begin{array}{c}40 \\
\text { DAP }\end{array}$ & $\begin{array}{c}60 \\
\text { DAP }\end{array}$ & $\begin{array}{c}20 \\
\text { DAP }\end{array}$ & $\begin{array}{c}40 \\
\text { DAP }\end{array}$ & $\begin{array}{c}60 \\
\text { DAP }\end{array}$ \\
\hline Candyman & 9.33 & 49.11 & 71.42 & 100.21 & 3.43 & 5.27 & 8.03 & 25.67 & 38.29 & 47.00 & 1.92 & 2.38 & 2.46 \\
\hline Nova Lux & 10.33 & 47.57 & 69.12 & 87.91 & 2.70 & 4.17 & 6.37 & 24.20 & 35.48 & 46.10 & 1.35 & 1.60 & 1.81 \\
\hline Gunjan & 13.33 & 42.45 & 58.91 & 86.02 & 3.03 & 6.07 & 7.47 & 23.23 & 32.78 & 44.36 & 1.35 & 1.72 & 2.71 \\
\hline Advantage & 11.00 & 47.31 & 68.81 & 88.83 & 2.73 & 5.77 & 6.13 & 23.79 & 33.51 & 42.33 & 1.80 & 2.07 & 2.17 \\
\hline Punjab Dawn & 8.67 & 40.89 & 54.31 & 85.43 & 3.00 & 5.07 & 6.57 & 24.26 & 34.04 & 45.29 & 1.24 & 1.53 & 2.50 \\
\hline Summer Sunshine & 9.67 & 42.31 & 72.31 & 84.83 & 2.97 & 4.80 & 7.50 & 21.71 & 33.12 & 43.37 & 1.74 & 2.20 & 2.74 \\
\hline Her Majesty & 11.00 & 40.33 & 62.00 & 71.97 & 2.40 & 4.63 & 7.13 & 20.48 & 28.02 & 38.07 & 1.09 & 1.22 & 1.95 \\
\hline Dull Queen & 10.33 & 30.34 & 43.37 & 53.70 & 2.90 & 4.37 & 6.03 & 17.63 & 26.61 & 38.90 & 1.11 & 1.31 & 1.74 \\
\hline Saffron & 9.67 & 42.14 & 60.52 & 70.47 & 2.53 & 4.50 & 6.87 & 22.57 & 32.95 & 42.74 & 1.17 & 1.64 & 2.20 \\
\hline GS-2 & 11.67 & 40.69 & 67.07 & 97.47 & 3.57 & 5.83 & 7.67 & 19.66 & 32.49 & 41.66 & 1.29 & 1.83 & 2.77 \\
\hline American Beauty & 9.67 & 33.88 & 43.60 & 68.41 & 2.73 & 4.83 & 6.97 & 23.81 & 27.69 & 37.14 & 1.35 & 1.75 & 2.14 \\
\hline White Prosperity & 9.67 & 47.94 & 65.04 & 89.17 & 3.07 & 4.90 & 7.87 & 18.12 & 36.52 & 47.70 & 1.75 & 2.36 & 2.81 \\
\hline Red Majesty & 11.33 & 43.44 & 69.00 & 81.21 & 3.00 & 4.33 & 6.20 & 23.70 & 32.23 & 40.86 & 1.74 & 2.13 & 2.19 \\
\hline Fancy Pink & 11.67 & 41.98 & 61.23 & 95.97 & 2.70 & 5.10 & 6.70 & 21.80 & 33.80 & 42.97 & 1.76 & 2.19 & 2.61 \\
\hline S.Em \pm & 0.81 & 1.88 & 2.00 & 0.57 & 0.21 & 0.23 & 0.37 & 1.57 & 1.09 & 0.96 & 0.06 & 0.11 & 0.14 \\
\hline C.D at $5 \%$ & 2.36 & 5.48 & 5.83 & 1.68 & 0.62 & 0.67 & 1.08 & 4.58 & 3.16 & 2.78 & 0.19 & 0.32 & 0.40 \\
\hline
\end{tabular}


Table.2 Performance of different gladiolus cultivars for corms and cormels production

\begin{tabular}{|c|c|c|c|c|c|}
\hline Treatments & $\begin{array}{l}\text { Number of corms } \\
\text { per plant }\end{array}$ & $\begin{array}{l}\text { Weight of corms } \\
\text { per plant }(\mathrm{g})\end{array}$ & $\begin{array}{l}\text { Diameter of } \\
\text { corms }(\mathbf{c m})\end{array}$ & $\begin{array}{c}\text { Number of cormels } \\
\text { per plant }\end{array}$ & $\begin{array}{l}\text { Weight of cormels } \\
\text { per plant }(\mathrm{g})\end{array}$ \\
\hline Candyman & 2.33 & 80.56 & 6.46 & 54.95 & 17.47 \\
\hline Nova Lux & 3.48 & 32.09 & 4.14 & 53.27 & 12.53 \\
\hline Gunjan & 2.48 & 31.69 & 4.19 & 72.92 & 32.49 \\
\hline Advantage & 4.69 & 42.33 & 4.74 & 49.18 & 10.67 \\
\hline Punjab Dawn & 2.99 & 39.12 & 4.28 & 35.35 & 13.53 \\
\hline Summer Sunshine & 2.14 & 58.71 & 5.36 & 42.82 & 11.43 \\
\hline Her Majesty & 3.31 & 33.01 & 4.43 & 52.75 & 16.15 \\
\hline Dull Queen & 3.32 & 21.15 & 3.27 & 120.79 & 30.89 \\
\hline Saffron & 3.82 & 33.41 & 4.17 & 83.49 & 18.27 \\
\hline GS-2 & 2.66 & 25.42 & 4.19 & 25.67 & 13.12 \\
\hline AmericanBeauty & 2.16 & 33.42 & 4.28 & 42.74 & 12.69 \\
\hline White Prosperity & 2.55 & 46.73 & 5.55 & 132.46 & 45.14 \\
\hline Red Majesty & 2.40 & 53.79 & 4.92 & 43.40 & 18.68 \\
\hline Fancy Pink & 3.73 & 49.61 & 4.81 & 44.83 & 21.61 \\
\hline S. $\mathbf{E m} \pm$ & 0.24 & 1.26 & 0.24 & 1.75 & 1.16 \\
\hline C.D at $5 \%$ & 0.71 & 3.67 & 0.69 & 5.10 & 3.36 \\
\hline
\end{tabular}


The cultivar White Prosperity (132.46) was significantly superior over all other cultivars under study, followed by Dull Queen (120.79) and lowest number of cormels (25.67) per plant was noted in the cultivar GS-2. The results for number of cormels plant ${ }^{-1}$ confirm with the findings of Mishra and Saini (1990), Jhon et al., (1996), Rani et al., (2007), Ranpise et al., (2007) and Hossain et al., (2011) in gladiolus.

The weight of cormels was highest in cultivar White Prosperity (45.14 g) followed by Gunjan (32.49 g) and lowest cormel weight per plant was recorded Advantage (10.67 g). Similar variations for weight of cormels per plant were also recorded by Nair and Shiva (2003), Nimbalkar (2007) and Kishan (2010).

\section{References}

Abbasi, N.A., Hafiz, I.A., Ahmad, T., Saleem, N. (2005). Growing Gladiolus, Proceedings of the National Seminar on Streamlining, Production and Export of Cut flowers and House plants, 2nd to 4th March, Hort. Found. Pak

Goldblatt, P., Manning, J.C., Bernhardt, P. (1998) Adaptive Radiation of BeePollinated Gladiolus Species in Southern Africa. Annals of the Missouri Botanical Garden. 85(3):492.

Ranpise, S.A., Nijasure, S.N. and Gondhali, B.V. (2010). Effect of preservatives on vase life of gladiolus cv. American beauty. J. Maharashtra Agri. Universities. 35(3): 446448.

Pandey, R.K., Bhat, D.J.I., Dogra, S., Singh, A., Laishram, N., Jamwal, S. (2012).
Evaluation of gladiolus cultivars under subtropical conditions of Jammu. Int. J. Agri. Sci. 8(2):518-522.

Kishan, Swaroop. (2010). Morphological variation and evaluation of gladiolus germplasm. Indian J. of Agri. Sci. 80(8): 742-745.

Nair, S.A. and Shiva, K.N. (2003). Performance of selected gladiolus (Gladiolus floribundus) varieties under Bay Island conditions. Indian J. of Agri. Sci. 73(7): 397-398.

Kumari, K. and Kumar. (2015). Evaluation of Performance of Gladiolus Varieties for Vegetative, Floral and Corm \& Cormel characters under Tarai conditions. Int. J. of Trop. Agri. 33(2): 1617- 1620.

Hossain, M.D., Talukder, K.H., Asaduzzaman, M., Mahmud, F., Amin, N. and Sayed, M.A. (2011). Study on morphological characteristics of different genotypes of gladiolus flower. J. Sci. Foundation. 9(1\&2): 01- 08.

Swaroop, K., JankiRam, T. and Naveen Kumar. (2011). Comparative performance of new gladiolus hybrids suitable for northern plains. J. of Orn. Hort. 14 (3\&4): 76-79.

Rani, R., Prasad, K.K. and Ranjan, R. (2007). Study on varietal performance in gladiolus. Orissa J. of Hort. 35(2): 35-38.

Jhon, A.Q., Bichoo, G.A. and Siddique, M.A.A. (1996). Performance of gladiolus cultivars in Kashmir. Flora and Fauna (Jhansi). 2(1): 75-77.

Nimbalkar, C.A., Katwate, S.M., Singh, B.R., Kakade, D.S. and Gurav, S.B. (2007). Selection strategy for improvement in economic traits of gladiolus. J. of Orn. Horti. 10(1): 9-14.

\section{How to cite this article:}

Shravan Kumar, T. Tirkey, Ram Singh, Ishwar Ram Markam and Durgeshwar Kumar Basant. 2020. Performance of Different Gladiolus (Gladiolus grandiflora L.) Cultivars for Plant Growth and Corm Production under Chhattisgarh Plains Agroclimatics Zone Condition. Int.J.Curr.Microbiol.App.Sci. 9(10): 2810-2816. doi: https://doi.org/10.20546/ijcmas.2020.910.338 